\title{
Determination of Temperature Limits for Radioactive Waste Tanks
}

by

B. J. Wiersma

Westinghouse Savannah River Company

Savannah River Site

Aiken, South Carolina 29808

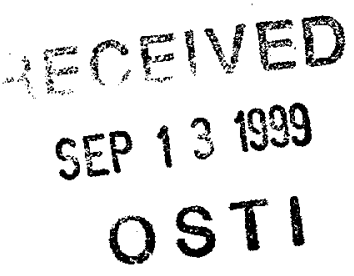

DOE Contract No. DE-AC09-96SR18500

This paper was prepared in connection with work done under the above contract number with the U. S. Department of Energy. By acceptance of this paper, the publisher and/or recipient acknowledges the U.S. Government's right to retain a nonexclusive, royalty-free license in and to any copyright covering this paper, along with the right to reproduce and to authorize others to reproduce all or part of the copyrighted paper. 


\title{
Determination of Temperature Limits for Radioactive Waste Tanks (U)
}

\author{
B. J. Wiersma
}

Savannah River Technology Center

Strategic Materials Department

Materials Technology Section

\section{Westinghouse Savannah River Company Savannah River Site Aiken, SC 29808}

This document was prepared in connection with work done under Contract No. DE-AC09-868R 18955 with the U. S. Depart ment of Energy. By acceptance of this document, the publisher and/or recipient acknowledges the U. S. Government's right to retain a nonexclusive, royalty-free license in and to any copyright covering this document, along with the right to reprodu and authorize others to reproduce all or part of the copyrighted material. 


\section{DISCLAIMER}

This report was prepared as an account of work sponsored by an agency of the United States Government. Neither the United States Government nor any agency thereof, nor any of their employees, makes any warranty, express or implied, or assumes any legal liability or responsibility for the accuracy, completeness, or usefulness of any information, apparatus, product, or process disclosed, or represents that its use would not infringe privately owned rights. Reference herein to any specific commercial product, process, or service by trade name, trademark, manufacturer, or otherwise does not necessarily constitute or imply its endorsement, recommendation, or favoring by the United States Government or any agency thereof. The views and opinions of authors expressed herein do not necessarily state or reflect those of the United States Government or any agency thereof.

This report has been reproduced directly from the best available copy.

Available to DOE and DOE contractors from the Office of Scientific and Technical Information, P.O. Box 62, Oak Ridge, TN 37831; prices available from (615) 576-8401.

Available to the public from the National Technical Information Service, U.S. Department of Commerce, 5285 Port Royal Road, Springfield, VA 22161. 


\section{DISCLAIMER}

Portions of this document may be illegible in electronic image products. Images are produced from the best available original document. 


\section{SMTD}

Strategic Materials Technology Department

Keywords: Corrosion

High Level Waste

Retention - Permanent

\section{Determination of Temperature Limits for Radioactive Waste Tanks (U)}

by

B. J. Wiersma

UNLLASSIFIEO

DOES NOT CONTAIN

UNCLASSIFIED CONTROLLED

NUCLEAR INFORMATION

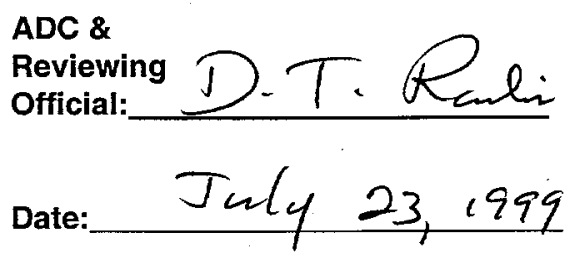


Westinghouse Savannah River Company

Prepared for the U.S. Department of Energy under Contract DE-AC09-89SR18035

WSRC-TR-98-00131, Rev. 1 (U)

\section{APPROVALS}

\section{Bune / Wusme}

B. J. Wiersha, Author

Materials Applications \& Corrosion Technology Group MATERIALS TECHNOLOGY SECTION

p. 3

P.E. Zapp, Technical Reviewer

Materials Applications \& Corrosion Technology Group MATERIALS TECHNOLOGY SECTION

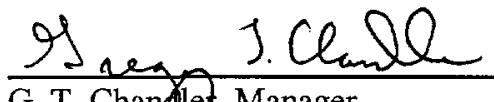

G. T. Chandlet, Manager

Materials Performance \& Corrosion Technology Group MATERIALS TECHNOLOGY SECTION

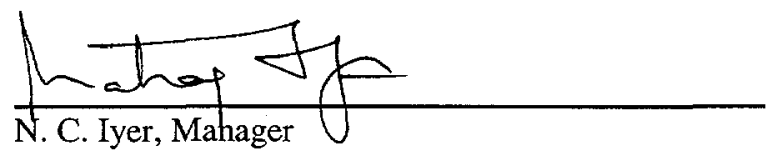

MATERIALS TECHNOLOGY SECTION

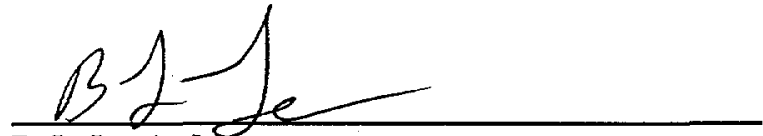

B. L. Lewis, Manager

Concentration, Storage, and Transfer Engineering
Date: $7-22-99$

Date: $7.28-59$

Date: $7 / 23 / 99$

Date:

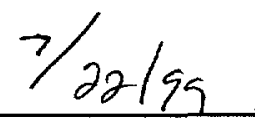




\section{Determination of Temperature Limits for Radioactive Waste Tanks}

\section{Summary}

A method was developed for the determination of temperature limits for radioactive waste tanks. Maintaining these temperature limits is part of an effective corrosion control program. Although there may be other reasons (e.g., presence of high volatility organic material) for maintaining lower temperatures than those specified in this document, as far as corrosion is concerned, these are the maximum temperature limits. For CSTE facilities ( $\mathrm{F}$ and $\mathrm{H}$ tank farms) these limits will be maintained by the CSTE organization and incorporated into the Emergency Response Document. The limits for the current waste compositions are shown in Table 1.

\section{Introduction}

Radioactive waste is stored in carbon steel tanks at the Savannah River Site. The waste chemistry in these tanks is maintained at an alkaline $\mathrm{pH}$ to minimize general corrosion of the carbon steel. However, localized corrosion mechanisms such as stress corrosion cracking and pitting have occurred. Besides the waste chemistry, the temperature of the waste has a strong effect on the rate at which these mechanisms initiate and propagate. Thus, corrosion control limits are specified not only for the tank chemistry, but for the temperature as well.

There are three regions in a tank where the temperature is measured: 1) the supernate phase (sup), 2) salt/sludge phase (ss), 3) the tank steel wall (w). The temperatures for the supernate and the salt/sludge phases in all tanks are measured by thermocouples that are installed at various heights within a thermowell. The height of the thermocouples depends on the level of the desired phase that will be measured. The highest recorded temperature in each of these phases should be compared with the temperature limits for each phase. All double shell (Type I, II, III, and MA) tanks have a single thermocouple that is attached to the outside of the primary tank approximately 25 " above the tank bottom. This position was selected because it was near the bottom horizontal girth weld where the stresses are the greatest. There are no sidewall thermocouples for the Type IV tanks. Requirements for maintenance and monitoring frequency are written in the Corrosion Control Program of the Technical Safety Requirements [1].

This document provides a systematic approach for determining the temperature limits for a tank given that the supernate concentration is known, or for "dry" tanks, given that the supernate concentration from the last sample of free supernate that was collected is known. A decision tree was developed (see Figure 1) to provide the logic for the temperature limit determination. The discussion section below provides the bases for the temperature limits specified in the decision tree. 


\section{$\underline{\text { Discussion }}$}

\section{Decision Tree}

A decision tree was developed to assign the appropriate temperature limits for the waste in each tank. The decision tree consists of thirteen numbered questions regarding the status of the tank and the limits or actions that stem from the answers to the questions. The temperature limits were assigned based on the corrosion behavior in a given waste environment (i.e., chemistry, temperature, etc.) rather than on the process function of the tank. For example, it has been shown that at nitrate concentrations greater than 1 molar, the primary corrosion mechanism is stress corrosion cracking (SCC). However, at nitrate concentrations less than 1 molar the primary corrosion mechanism is pitting. The concentrations of the major components of the waste and the temperature in each tank are shown in Table 1. These were taken from the March 1998 Emergency Response Document (ERD) [2].

From this table it is observed that there are three categories of waste chemistry: 1) Tanks where the nitrate concentration is greater than 1 molar, 2) Tanks where the nitrate concentration is less than 1 molar, and 3) Tanks where there is no free supernate. These three categories were utilized as the high-level decision points in the development of the tree. As will be discussed, the corrosion mechanisms for each category will differ.

Decision 1: The first decision point determines whether or not free supernate is available to sample for analysis. If there is no free supernate, there is no temperature limit for the supernate. However, there will be temperature limits for the salt or sludge phase, the tank wall and the tank bottom (see discussion on Decisions 11-13). If supernate is available, the next decision point will distinguish between different nitrate concentration levels, and hence corrosion mechanisms.

Decision 2: The nitrate SCC mechanism in carbon steels depends heavily on the nitrate concentration, the concentration of inhibitors, and the temperature [3]. It has been shown that in general, SCC occurs at supernate nitrate concentrations greater than 1 molar and at temperatures above $70^{\circ} \mathrm{C}$. The presence of a sufficient concentration of sodium hydroxide and sodium nitrite has been shown to inhibit against initiation and propagation of SCC [4]. The inhibitor concentration requirements depend on the nitrate concentration. These requirements are shown in Table 2 .

\section{Concentrated Wastes}

Decision 3: The factor $\mathrm{R}$ is the ratio of the molar concentration of inhibitor species (sodium hydroxide and sodium nitrite) to the aggressive species (sodium nitrate) [3]. The ratio was utilized to determine appropriate temperature limits for waste storage and waste removal operations when the supernate nitrate concentration is greater than 1 molar. For ratios less than 0.2 , the limit is $70^{\circ} \mathrm{C}$. This may occur if the nitrate concentration exceeds $5.5 \mathrm{M}$. Currently there are no tanks with this high nitrate concentration, but this may happen during waste removal operations. If the ratio is between $0.2-2.0$, there are three 
cases. Laboratory tests in simulated waste, at nitrate concentrations between 1 to 2.75 molar and temperatures greater than $70^{\circ} \mathrm{C}$, demonstrated moderate corrosivity towards carbon steel. Therefore the temperature limit was set at $70^{\circ} \mathrm{C}$ [4]. In tests performed in solutions, at nitrate concentrations between 2.75 to 5.5 molar and similar temperatures, insignificant attack occurred and thus the boiling point temperature was set as the limit. Solutions tested at concentrations greater than 5.5 molar indicate that in this range moderate corrosivity is observed at temperatures greater than $70^{\circ} \mathrm{C}$. For ratios greater than 2 , the recommended temperature limit is the boiling point since these wastes are not corrosive. If the nitrate concentration is greater than 5.5 molar, it is not possible for the $\mathrm{R}$ ratio to be greater than 2 due to solubility limitations [5].

Therefore, the decision point determines whether the boiling point is an acceptable temperature limit for the supernate. If $\mathrm{R}$ is less than $2,70^{\circ} \mathrm{C}$ may be the acceptable temperature limit.

Decision 4: As determined from decision 3, the boiling point is the acceptable temperature limit for the case with $\mathrm{R}$ greater than 2 . An equation was developed to estimate the boiling point given the total molarity of the waste [6].

$$
\mathrm{T}_{\mathrm{bp}}(\mathrm{C})=100+(\text { total molarity }) * 1.03^{\circ} \mathrm{C}-\text { liter } / \text { mole }
$$

This equation was utilized to determine the average boiling point for the nitrate concentration ranges 1 to 2.75 molar and 2.75 to 5.5 molar. The 5.5 to 8.5 molar nitrate concentration range was not considered due to solubility limitations. The boiling point was estimated in the following manner. It was assumed that since the primary components of the waste were nitrate, nitrite, and hydroxide, that the sum of these three molar concentrations could be utilized to determine the total molarity. The boiling point temperature was then determined at the lower end of the concentration range assuming that $\mathrm{R}$ was 2 . For example, if the nitrate concentration is 1 molar, the sum of the hydroxide and nitrite concentrations would be 2 molar, and thus the total molarity would be 3 molar. Substituting this value into Equation 1 gives an estimated boiling point of $103^{\circ} \mathrm{C}$. Performing a similar calculation using a nitrate concentration of $2.75 \mathrm{M}$, an estimated boiling point of $108^{\circ} \mathrm{C}$ is obtained. The average of these two temperatures is $105 \pm 3^{\circ} \mathrm{C}$. A temperature of $105^{\circ} \mathrm{C}$ was determined to be an acceptable limit for wastes within this supernate concentration range. Several tanks have R-values much greater than 2 (see Table 1). This results in estimated boiling points that are well above the $105^{\circ} \mathrm{C}$ limit (see Table 1). Thus setting the limit at this value will actually underestimate the actual boiling point in many cases.

The same assumptions and calculations were made for the nitrate concentration between 2.75 to $5.5 \mathrm{M}$. In this case the average estimated boiling point was $112^{\circ} \mathrm{C}$. Again this is a conservative value, but remains well above the current temperatures of the waste supernates.

Decision 5: This decision point provides temperature limits for the cases in which $\mathrm{R}$ is less than 2. As mentioned above under decision 3 , if the nitrate concentration is between 
2.75 to 5.5 molar the temperature limit for the supernate is the boiling point. For the other two concentration ranges $70^{\circ} \mathrm{C}$ is the limit for the supernate. The boiling point is estimated by the same procedure as above. The minimum inhibitor concentrations for hydroxide and nitrite were utilized to calculate the total molarity. The average estimated boiling point for the nitrate concentration in the range 2.75 to 5.5 molar the estimated boiling point was $105^{\circ} \mathrm{C}$. The temperature of $105^{\circ} \mathrm{C}$ was established as a single value for the boiling point. Given that the effect of the hydrostatic head is being neglected [7] this is a reasonable estimate for the boiling point.

The temperature limits obtained from this portion of the decision tree are summarized again in Table 3.

Decisions 6 and 7: The temperature limits for the salt and sludge phases $\left(T_{s s}\right)$ and the steel wall $\left(\mathrm{T}_{\mathrm{w}}\right)$ are based on maintaining a liquid phase containing inhibitors at the tank wall. In the past, these temperatures have been of particular concern for the tanks designated as fresh waste receivers. In this situation, the composition of the interstitial liquid in the salt and/or sludge, and hence the liquid which is in contact with the bottom and wall of the primary, is not completely known. However, laboratory tests and analysis of actual interstitial liquid have shown that for saltcake the $\mathrm{R}$ ratio is much greater than 2 [8]. The interstitial liquid present in sludge has also been characterized [9]. In general, the nitrate concentration in the supernate above the sludge was greater than that observed in the sludge interstitial liquid. It is likely that the nitrate concentration decreased due to ionizing radiation that converts the nitrate to the inhibitor species nitrite. Thus as the sludge ages, the $\mathrm{R}$ factor of the interstitial liquid increases indicating a decrease in the corrosivity of the liquid. For these reasons the temperature limits for the salt/sludge and the steel wall is the boiling point.

Care should be taken that the boiling point is not exceeded. If the temperature exceeds the boiling point, it may be possible to produce a nitrate-rich salt at the wall or bottom of the tank that would not protect the steel from SCC [10]. As the waste aged and cooled, there would be a potential for water or supernate to re-dissolve this salt. The composition of this new waste would be difficult to predict and hence the potential for SCC would be difficult to predict. Therefore it is necessary to ensure that this mechanism does not occur by limiting the temperature to the boiling point.

The boiling point temperature elevation is calculated on the basis of the volume and the specific gravity of the waste in each tank [11]. The static head of the waste above the location of the thermocouples that measure $\mathrm{T}_{\mathrm{ss}}$ and $\mathrm{T}_{\mathrm{w}}$ elevates the boiling point temperature above the supernate boiling point temperature [7]. The Clausius-Clapeyron equation relates the boiling point elevation to the static head pressure due to the liquid depth. Table 1 shows that most of the concentrated waste (nitrate $>1$ molar) has a specific gravity greater than 1.25 . If a tank contains 120 inches of free supernate, the total pressure at a level 120 inches below the top of the supernate due to the liquid head, assuming a specific gravity of 1.25 , is 20.1 psia. Substituting this pressure into the Clausius-Clapeyron equation, a boiling point elevation of $10^{\circ} \mathrm{C}$ is calculated. 
Therefore, it is recommended that the temperature limit for $T_{s s}$ and $T_{w}$ be determined not only by the supernate boiling point temperature but also the depth of waste. If the depth of waste is greater than 120 inches the temperature, $T_{s s}$ and $T_{w}$ should be $10^{\circ} \mathrm{C}$ greater than the boiling point of the supernate. Depending on the composition of the supernate, these temperatures would be either $115^{\circ} \mathrm{C}$ or $122^{\circ} \mathrm{C}$. If the depth of waste is less than 120 inches, $T_{s s}$ and $T_{w}$ should remain the same as the boiling point of the supernate. In many cases, this is a conservative approach (i.e., the boiling point is actually higher) as the amount of waste in a tank is much greater than 120 inches. This simplified approach will also eliminate the difficulty of determining the elevation difference between the top of the supernate and the thermocouple that is being utilized to measure the temperature.

These temperature limits are also well above the current values for $T_{S S}$ and $T_{w}$ observed for most waste tanks. In most cases the observed temperatures are less than $60^{\circ} \mathrm{C}$. Tank 32 achieves the highest observed $T_{s s}$ and $T_{w}$. During most of the year, the highest temperature observed is in the mid-80's. However, if the cooling coils and the ventilation are out of service for extended periods of time (e.g., 6 months), $T_{w}$ has been observed to rise into the high-90s or low-100s. Therefore, this tank should probably be monitored carefully to ensure that the temperature limits are not exceeded. The new temperature limit for $T_{w}$, based on this analysis, will be $115^{\circ} \mathrm{C}$, which is well above the observed temperature. Although Tw and Tss were calculated by the same method, Tw will be adjusted by $5^{\circ} \mathrm{C}$ to account for the temperature drop across the steel wall surface.

Table 4 summarizes the temperature limits for the salt/sludge phases and the steel wall.

\section{Dilute Wastes}

As mentioned above, at nitrate concentrations less than 1 molar the dominant corrosion mechanism is pitting. There are two regions of the tank where pitting is a concern. The first region occurs at the vapor/liquid interface. Here a thin wetted film forms on the tank wall above the liquid level [12]. This film absorbs carbon dioxide that reacts with the hydroxide to form carbonate and bicarbonate. Unless there is sufficient hydroxide or nitrite in the bulk waste to replenish this film with inhibitors by diffusion processes, this layer becomes uninhibited and pitting results. The second area is in the walls in contact with the bulk liquid. Depletion of hydroxide is slower in the bulk liquid than for the thin film, however, given enough time it will occur here also. Tanks that have a small volume of waste or low hydroxide concentration are most susceptible to inhibitor depletion [13].

There are two schemes for inhibiting nitrate induced pitting: 1) sodium hydroxide alone, or 2) sodium nitrite with a minimum hydroxide level. Decision points 8 through 10 determine the appropriate temperature given the inhibitor scheme.

Decision 8: The first decision point distinguishes between the two inhibitor schemes. If the hydroxide concentration is greater than 1 molar the sodium hydroxide scheme has been selected. Laboratory tests have shown that no pitting is observed in simulated dilute waste that contains greater than 1 molar hydroxide $[14,15]$. A theoretical model also 
demonstrated that a minimum hydroxide concentration of $1 \mathrm{M}$ is sufficient to maintain a minimum $\mathrm{pH}$ of 12 in the wetted film region [12].

Decision 9: At high hydroxide concentrations stress corrosion cracking may become a concern. In hot caustic solutions carbon steel may become susceptible to caustic stress corrosion cracking. Laboratory testing was performed in simulated wastes that contained between 1 to 8 molar sodium hydroxide, 0.02 to 1.0 molar sodium nitrate, and at temperatures between 50 to $100^{\circ} \mathrm{C}[16,17]$. The results of the tests demonstrated that the presence of a small amount of nitrate was enough to prevent caustic cracking within these environmental conditions. If less than 0.02 molar nitrate is present there is a potential for caustic cracking at high temperatures. Therefore, for nitrate concentrations less 0.02 molar the temperature limits were set at $60^{\circ} \mathrm{C}$.

Decision 10: If the hydroxide concentration exceeds 8 molar, the carbon steel may again become susceptible to caustic stress corrosion cracking. Therefore, for this case, the temperature limits are also $60^{\circ} \mathrm{C}$. Otherwise a temperature of $100^{\circ} \mathrm{C}$ may be utilized for the temperature limits.

Decision 11: If the hydroxide concentration is less than 1 molar, the waste is inhibited with nitrite and a minimum amount of hydroxide. The steady-state $\mathrm{pH}$ depends on the initial hydroxide and carbonate concentrations in the waste and the carbon dioxide concentration in the air. The lowest steady state $\mathrm{pH}$ that has been tested is 10.3 , and is the minimum specified for all nitrate concentrations below 1 molar [18].

The temperature limits for tanks that meet these conditions were based on the criteria that the liquid would always have sufficient inhibitor to prevent attack at temperatures less than $40^{\circ} \mathrm{C}$. This establishment of this criterion determines when inhibitor additions should be performed. Previously, the temperature limit shifted depending on the measured nitrate concentration. Since this measurement can fluctuate significantly due to analytical error and depletion mechanisms, the temperature limit would also shift. The potential that the temperature limit would approach the actual temperature of the tank existed. The $40^{\circ} \mathrm{C}$ temperature, on the other hand, is sufficiently above the normal operating temperature (i.e., 18 to $32^{\circ} \mathrm{C}$ ) of the tanks which contain dilute waste, while at the same time not resulting in the addition of excess inhibitor.

The primary aggressive species in dilute solutions is the nitrate anion [14], although at very dilute nitrate concentrations, the chloride or sulfate ion may become the aggressive species [19]. There are four possible conditions in the dilute waste: 1) the waste has aggressive anion concentrations less than 0.02 molar, 2) nitrate is the aggressive species, 3) chloride is the aggressive species, and 4) sulfate is the aggressive species. The equations for the minimum nitrite concentration required to prevent pitting for each condition are shown in Table 2. From these equations the minimum ratio of the nitrite to aggressive species, A, can be calculated for a waste at $40^{\circ} \mathrm{C}$. These ratios and the constant values for each condition, MIN, are shown below. 
$\mathrm{A}<0.02 \mathrm{M}: \quad\left[\mathrm{NO}_{2}^{-}\right] \geq 0.033$

Nitrate: $\quad\left[\mathrm{NO}_{2}{ }^{-}\right] /\left[\mathrm{NO}_{3}{ }^{-}\right] \geq 1.65$

Chloride: $\quad\left[\mathrm{NO}_{2}{ }^{-}\right] /\left[\mathrm{Cl}^{-}\right]^{1.34} \geq 267$

Sulfate: $\quad\left[\mathrm{NO}_{2}{ }^{-}\right] /\left[\mathrm{SO}_{4}{ }^{=}\right]^{0.84} \geq 1.75$

A review of these equations showed that if any one of these requirements is violated, then inhibitor should be added to the waste [20]. The maximum value obtained from these equations determines the minimum nitrite concentration. The amount of nitrite added to the waste shall correspond to the value from the equation in which the requirement was violated, or if more than one requirement was violated, the value from the equation which calculates the largest nitrite concentration.

Decision 12: This decision point determines whether or not there is a sludge or salt phase present beneath the supernate. If no sludge or saltcake is present, no temperature limit is assigned. For waste tanks that contain a solids phase beneath a dilute waste, with less than 1 molar hydroxide, the temperature limit is $75^{\circ} \mathrm{C}$. The corrosion concern is that regions of localized high temperature will develop and result in pitting attack on the tank wall or bottom. Laboratory tests have shown that if the hydroxide concentration is greater than 0.01 molar in the bulk supernate above the solids phase, no pitting will occur at temperatures less than $75^{\circ} \mathrm{C}[21]$.

Table 5 summarizes the temperature limits for the dilute wastes.

\section{"Dry" Waste}

The supernate in nine tanks has been allowed to evaporate leaving either a saltcake or sludge layer phase. Although there is no supernate above, these phases may contain interstitial liquid that may cause a corrosion concern. Due to the various mechanisms of concentration and depletion that can occur in the interstitial liquid, the composition of the interstitial liquid is difficult to predict. The concentrating mechanisms tend to reduce the corrosivity of the interstitial liquid. As water evaporates from the liquid, sodium nitrate crystallizes preferentially to sodium nitrite and sodium hydroxide. As more water is evaporated eventually sodium nitrite begins to crystallize preferentially to the sodium hydroxide [22]. The result of this process is that the interstitial liquid becomes more caustic. Additionally, the nitrate that remains in the interstitial liquid is reduced to nitrite by ionizing radiation [23]. Both of these mechanisms would suggest that the composition of the interstitial liquid becomes less corrosive over time.

Another favorable factor as time increases is that the volume of interstitial liquid will decrease as evaporation proceeds. If the water from the interstitial liquid has evaporated, there would be no conductive medium for a corrosion cell. Evaporation has probably been more significant in the sludge than in the salt due to the higher heat generation rate 
in the sludge. The interstitial liquid in Tank 5 has very likely evaporated completely given that the waste has been "dry" for a significant time period $(~ 25$ years $)$ and the initial sludge level was very low ( 12"). Significant amounts of interstitial liquid may have also evaporated from Tanks 8 and 12. A pool of liquid however, was observed on top of the Tank 15 sludge as recently as two or three years ago indicating that the sludge may still contain a significant quantity of interstitial liquid.

Other mechanisms, on the other hand, have been shown to deplete corrosion inhibitors. Hobbs has also been shown that the hydroxide is depleted due to a reaction with carbon dioxide from the air [13]. This process is slow, however, given enough time (i.e., 40-50 years) and a small enough liquid volume ( $<10 \%$ of the volume of the tank), the depletion may become significant. This hydroxide depletion time was calculated assuming that the initial free hydroxide was concentration was $1.87 \mathrm{M}$ and the final $\mathrm{pH}$ was 12 . This calculation was conservative because it was assumed that the sludge or salt layer was saturated with liquid. Table 6 shows the estimated time for hydroxide depletion given the $\%$ volume of tank space that is occupied by waste in existing dry waste tanks [13]. For comparison, the length of time the tank has been dry is also shown. The results show that for four of the tanks $(2,8,12,15)$ the hydroxide in the interstitial liquid has probably not been depleted. It is also unlikely that the hydroxide has been completely depleted from the tanks that have been "dry" for longer than the estimated depletion time. The free hydroxide concentration of the most recent samples from Tanks 3, 9, and 14 were at least two times greater than that assumed for the calculation (i.e., 1.87 molar). Therefore, the actual depletion times are probably longer than those shown in the table are. Tank 10 is a borderline case, although the assumption that the last sample is representative of the interstitial liquid concentration is probably erroneous because prior to the last sample salt dissolution was performed in this tank. The hydroxide concentration of the interstitial liquid in the salt is more likely to be similar to the supernate concentration during the initial stages of density gradient removal. In 1976, prior to waste removal the free hydroxide concentration of the supernate was 3.9 molar, very similar to Tank 9 . Therefore, it is likely that the waste in this tank, similar to the three previous tanks, also has a high initial free hydroxide concentration. Tank 5 also had a short depletion time. However, as stated above it is very likely that the interstitial liquid has evaporated from this tank.

Another danger for the "dry" tanks is the inadvertent addition of uninhibited water to the tank. An example of an inadvertent addition is rainwater leakage through a riser or transfer line penetration. The rainwater dissolves salt that is present on top of the sludge layer or saltcake. The salt is primarily sodium nitrate with only a small amount of sodium hydroxide. The solution that forms may be very corrosive. The composition of the salt would be very difficult to predict. The amount of uninhibited water that is inadvertently added is generally very small ( $<1000$ gallons) and therefore would be expected to have only a minor effect in localized areas. Controls are being proposed that will limit the amount of uninhibited water that may be added to a tank [1]. If this limit is exceeded, an engineering evaluation will be performed to determine whether inhibitors shall be added. 
Given the relatively short time frame (1-25 years) that these tanks have been dry it is likely that the concentrating mechanism and the depletion of nitrate from the supernate predominates. Solution that forms due to the inadvertent addition of uninhibited water will also eventually evaporate and concentrate. Therefore, it is more likely that the interstitial liquid has become less corrosive over time.

Therefore, a conservative estimate of the interstitial liquid concentration is that it has the same composition as the supernate that was above the sludge or salt layer prior to the time when the tank became "dry". The actual hydroxide concentration of the interstitial liquid is probably actually higher due to evaporation processes or the fact that salt dissolution was performed in the tank. Therefore, the composition results from the most recent sample that was obtained will be utilized to estimate the composition of the interstitial liquid. This composition will be utilized to determine the temperature limits.

Table 6 shows the compositions of the most recent sample taken from these tanks. In some cases the last sample was taken almost 25 years ago. In each case the supernate was within the corrosion requirements. These compositions were utilized to make decisions 13 through 15.

Decision 13: This decision point is the same as decision point 2. The decision point determines the corrosion mechanism of concern. All of the "dry" tanks had nitrate concentrations greater than 1 molar. Therefore, stress corrosion cracking was the mechanism of concern. The requirement for the case if a dilute solution was above sludge or salt is the same as that for decision point 10 .

Decision 14: This decision point is the same as decision point 3. The difference is that since there is no supernate, the only temperature requirement is the boiling point. The method for determining the boiling point is the same as described above.

Decision 15: This decision point is the same as decision point 4. Again the boiling point is determined by the same method described previously.

\section{$\underline{\text { Application }}$}

The logic of the decision tree will be incorporated into an Excel ${ }^{\mathrm{TM}}$ spreadsheet. The necessary data from the Emergency Response Document (ERD), such as nitrate, nitrite, and hydroxide concentrations from each tank, will be input into the spreadsheet. The spreadsheet will then determine the temperature limits for each tank. These temperatures will then be reported in the ERD. As new samples are taken, and thus new waste compositions are determined, the temperature limits will be updated.

\section{Conclusion}

The basis for temperature limits for the supernate, salt or sludge phase, and the tank steel wall was described. A decision tree was developed from these bases, which determines each of the temperature limits for a given tank. The decisions are based on the waste 
chemistry data shown in the Emergency Response Document and the corrosion control requirements. The logic from this decision tree was incorporated into an Excel ${ }^{\mathrm{TM}}$ spreadsheet. The spreadsheet with input from the ERD was then utilized to determine the temperature limits. These temperature limits are then reported in the ERD. The basis for a single value for the boiling point was also presented in this document.

\section{Acknowledgements}

The author recognizes the efforts of a group of scientists and engineers who came to a consensus on these temperature limits: B. J. Wiersma, P. E. Zapp, T. C. Hsu, L. S. Livingston, J. A. Pike, E. D. Lee, and W. R. Parish.

\section{$\underline{\text { References }}$}

1. TSR Administrative Control Compliance Requirements, Corrosion Control Program, Appendix 6, Rev. 1.

2. F/H Tank Farm Emergency Response and Waste Tank Status Data, N-ESR-G00001, Rev. 22, March 1998.

3. B. J. Wiersma, "Clarification of Temperature Limits for Waste Solutions with Nitrate Concentrations Greater than 1 Molar (U)", WSRC-TR-94-0333, August 8, 1994.

4. R. S. Ondrejcin, "Prediction of Stress Corrosion of Carbon Steel by Nuclear Process Liquid Wastes", DP-1478, August, 1978.

5. J. I. Mickalonis, "Maximum Solubilities of Sodium Nitrate in Simulated Waste (U)", SRT-MTS-94-2043, October, 1994.

6. B. V. Churnetski, "Fresh Waste Boiling Point Determinations", DPST-82-289, March 3, 1982.

7. J. M. Smith and H. C. Van Ness, "Introduction to Chemical Engineering Thermodynamics", McGraw-Hill, New York, NY, p. 185, 1975.

8. D. T. Hobbs and C. J. Coleman, "Final Report: Analysis of Tank 41H Saltcake Sample \#2 and Comparison to Sample \#1 (U)", WSRC-TR-94-057, January 26, 1994.

9. J. A. Stone, "Detailed Analyses of SRP High-Level Waste Sludges", DPST-76425, October 6, 1976.

10. R. S. Ondrejcin, "Temperature Operational Limits for Nuclear Waste Tanks", DPST-83-1043, November 29, 1983.

11. M. S. Peters and R. A. Scaggs to J. H. Hershey, "Waste Tank Temperature Control Point", October 12, 1981.

12. D. T. Hobbs and R. M. Wallace, "Depletion of Hydroxide in Wetted Films Above Alkaline Solutions (U)", WSRC-TR-90-303, September 7, 1990.

13. D. T. Hobbs and R. M. Wallace, "Hydroxide Depletion in Waste Storage Tanks by Reaction with Carbon Dioxide", DPST-85-846, October 14, 1985.

14. P. E. Zapp, "Electrochemical Study of Corrosion Inhibition During Sludge Washing", DPST-88-399, March 14, 1988.

15. J. W. Congdon and J. S. Lozier, "Inhibition of Washed Sludge with Sodium Nitrite", DPST-87-379, April 7, 1987. 
16. J. D. Fritz, "Susceptibility of Waste Tanks to Stress Corrosion Cracking From DWPF In-Tank Alumina Dissolution", DPST-88-310, February 8, 1988.

17. J. D. Fritz, "Control of Stress Corrosion Cracking During DWPF In-Tank Alumina Dissolution", DPST-88-252, January 25, 1988.

18. P. E. Zapp, "Effect of Temperature on the Nitrite Requirement to Inhibit Washed Sludge (U)", WSRC-TR-90-292, September 18, 1990.

19. P. E. Zapp, "Recommended Nitrite Limits for Chloride and Sulfate in ESP Slurries (U)", WSRC-TR-94-0250, June 6, 1994.

20. Private Communication with P. E. Zapp, March 1998.

21. P. E. Zapp, "Technical Basis for a Minimum Hydroxide Concentration in Tanks Containing Dilute Waste (U)", WSRC-TR-95-0213, May 22, 1995.

22. C. B. Goodlett, "Concentration of Radioactive Wastes", DP-1135, June 1968.

23. M. L. Hyder, "The Radiolysis of Aqueous Nitrate Solutions", J. Phys. Chem., 69, $1858,(1965)$. 
Table 1. Tank Temperature Data*

\begin{tabular}{|c|c|c|c|c|c|c|c|c|c|c|c|c|}
\hline Tank & Date & $\begin{array}{l}\text { Specific } \\
\text { Gravity }\end{array}$ & $\begin{array}{c}\text { Free } \\
\text { supernate } \\
\text { level }\end{array}$ & $\mathrm{NO} 3$ & NO2 & $\mathrm{OH}$ & $\mathrm{R}$ & $\begin{array}{c}\mathrm{T}_{\text {sup }} \\
.\end{array}$ & $\begin{array}{l}\text { BP } \\
\text { Est. }\end{array}$ & $\begin{array}{l}\mathrm{T}_{\text {sup }} \\
\text { limit }\end{array}$ & $\begin{array}{c}\mathrm{T}_{\mathrm{ss}} \\
\text { limit }\end{array}$ & $\begin{array}{l}T_{w}{ }^{* * *} \\
\text { limit }\end{array}$ \\
\hline Units & & & inches & $\mathrm{M}$ & $\mathrm{M}$ & M & & $\begin{array}{l}\text { Temp } \\
\text { (C) }\end{array}$ & $\begin{array}{l}\text { Temp } \\
\text { (C) }\end{array}$ & $\begin{array}{l}\text { Temp } \\
\text { (C) }\end{array}$ & $\begin{array}{l}\text { Temp } \\
\text { (C) }\end{array}$ & $\begin{array}{l}\text { Temp } \\
\text { (C) }\end{array}$ \\
\hline 1 & $10 / 97$ & 1.53 & 7 & 2.00 & 2.75 & 9.30 & 6.03 & N/A & 115.4 & 105 & 115 & 115 \\
\hline 2 & - & - &.- & - & - & - & - & N/A & & N/A & 105 & 105 \\
\hline 3 & - & - & - & - & - & - & - & N/A & & N/A & 105 & 105 \\
\hline 4 & $12 / 97$ & 1.33 & 128 & 2.66 & 1.98 & 2.53 & 1.70 & $33^{\circ} \mathrm{C}$ & 108.3 & 70 & 115 & 115 \\
\hline 5 & - & - & - & - & - & - & - & N/A & & N/A & 105 & 105 \\
\hline 6 & $12 / 97$ & 1.06 & 118 & 0.032 & 0.37 & 0.39 & & $29^{\circ} \mathrm{C}$ & & 40 & 40 & 75 \\
\hline 7 & $12 / 97$ & 1.31 & 58 & 1.37 & 0.92 & 3.52 & 3.24 & $34^{\circ} \mathrm{C}$ & 107.0 & 105 & 115 & 115 \\
\hline 8 & - & - & - & - & - & - & - & N/A & & N/A & 105 & 105 \\
\hline 9 & - & - & - & - & - & - & - & N/A & & N/A & 105 & 105 \\
\hline 10 & 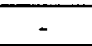 & - & - & - & - & - & - & N/A & & N/A & 105 & 105 \\
\hline 11 & $5 / 97$ & 1.38 & 74 & 3.32 & 2.19 & 0.82 & 0.91 & $33^{\circ} \mathrm{C}$ & 107.3 & 105 & 105 & 105 \\
\hline 12 & - & - & - & - & - & - & - & N/A & & N/A & 105 & 105 \\
\hline 13 & $9 / 97$ & 1.45 & 188 & 1.22 & 1.28 & 6.63 & 6.48 & $41^{\circ} \mathrm{C}$ & 110.3 & 105 & 115 & 115 \\
\hline 14 & - & - & - & - & - & - & - & N/A & & N/A & 105 & 105 \\
\hline 15 & - & - & - & - & - & - & - & N/A & & N/A & 105 & 105 \\
\hline 18 & $2 / 98$ & 1.00 & 87 & 0.007 & 0.041 & 0.05 & & $23^{\circ} \mathrm{C}$ & & 40 & 40 & N/A \\
\hline 19 & $1 / 98$ & 1.26 & 72 & 1.64 & 1.52 & 0.43 & 1.19 & $19^{\circ} \mathrm{C}$ & 105.2 & 70 & 105 & N/A \\
\hline 21 & $1 / 98$ & 1.1 & 33 & 0.13 & 0.38 & 0.38 & & $17^{\circ} \mathrm{C}$ & & 40 & 40 & N/A \\
\hline 22 & $1 / 98$ & 1.05 & 259 & 0.045 & 0.12 & 0.49 & & $19^{\circ} \mathrm{C}$ & & 40 & 40 & N/A \\
\hline 23 & $1 / 98$ & 1.02 & 191 & 0.025 & 0.11 & 0.14 & & $21^{\circ} \mathrm{C}$ & & 40 & 40 & N/A \\
\hline 24 & $1 / 98$ & 1.06 & 78 & 0.031 & 0.34 & 0.28 & & $20^{\circ} \mathrm{C}$ & & 40 & 40 & $\mathrm{~N} / \mathrm{A}$ \\
\hline 25 & $2 / 98$ & 1.45 & 46 & 1.34 & 1.30 & 9.22 & 7.85 & $34^{\circ} \mathrm{C}$ & 113.0 & 105 & 115 & 115 \\
\hline 26 & $2 / 98$ & 1.40 & 104 & 2.14 & 1.0 & 5.74 & 3.15 & $57^{\circ} \mathrm{C}$ & 111.1 & 105 & 115 & 115 \\
\hline 27 & $7 / 97$ & 1.48 & 229 & 2.00 & 1.34 & 9.54 & 5.44 & $27^{\circ} \mathrm{C}$ & 114.5 & 105 & 115 & 115 \\
\hline 28 & $8 / 97$ & 1.44 & 53 & 1.94 & 1.44 & 7.79 & 4.76 & $48^{\circ} \mathrm{C}$ & 112.3 & 105 & 115 & 115 \\
\hline 29 & $1 / 98$ & 1.36 & 78 & 1.74 & 1.84 & 4.51 & 3.65 & $34^{\circ} \mathrm{C}$ & 111.7 & 105 & 115 & 115 \\
\hline 30 & $9 / 97$ & 1.40 & 310 & 3.14 & 1.17 & 4.57 & 1.83 & $30^{\circ} \mathrm{C}$ & 109.9 & 105 & 115 & 115 \\
\hline 31 & $9 / 97$ & 1.45 & 70 & 2.90 & 1.98 & 5.06 & 2.43 & $30^{\circ} \mathrm{C}$ & 111.4 & 112 & 112 & 122 \\
\hline 32 & $6 / 97$ & 1.27 & 293 & 2.58 & 1.09 & 1.44 & 0.98 & $33^{\circ} \mathrm{C}$ & 106.0 & 70 & 115 & 115 \\
\hline 33 & $2 / 98$ & 1.18 & 55 & 1.4 & 0.06 & 1.22 & 0.92 & $31^{\circ} \mathrm{C}$ & 103.8 & 70 & 115 & 115 \\
\hline 34 & $8 / 97$ & 1.38 & 262 & 2.66 & 0.85 & 4.87 & 2.15 & $35^{\circ} \mathrm{C}$ & 109.0 & 105 & 115 & 115 \\
\hline 35 & $6 / 97$ & 1.31 & 325 & 3.08 & 0.94 & 1.64 & 0.84 & $29^{\circ} \mathrm{C}$ & 106.7 & 105 & 115 & 115 \\
\hline 36 & 9/97 & 1.46 & 52 & 1.57 & 1.75 & 9.68 & 7.28 & $27^{\circ} \mathrm{C}$ & 114.0 & 105 & 115 & 115 \\
\hline 37 & $6 / 97$ & 1.43 & 75 & 2.68 & 1.52 & 6.15 & 2.86 & $37^{\circ} \mathrm{C}$ & 111.5 & 105 & 115 & 115 \\
\hline 38 & $2 / 98$ & 1.41 & 85 & 1.85 & 1.77 & 5.88 & 4.14 & $45^{\circ} \mathrm{C}$ & 108.4 & 105 & 115 & 115 \\
\hline 39 & 9/97 & 1.22 & 271 & 1.63 & 0.59 & 3.10 & 2.26 & $23^{\circ} \mathrm{C}$ & 105.9 & 105 & 115 & 115 \\
\hline 43 & $11 / 97$ & 1.20 & 241 & 0.81 & 0.82 & 3.37 & 5.17 & $32^{\circ} \mathrm{C}$ & 105.5 & 100 & 100 & 100 \\
\hline 44 & $5 / 97$ & 1.51 & 80 & 1.50 & 1.31 & 11.69 & 8.67 & $30^{\circ} \mathrm{C}$ & 115.2 & 105 & 115 & 115 \\
\hline 45 & $5 / 97$ & 1.53 & 38 & 1.57 & 1.55 & 13.40 & 9.52 & $35^{\circ} \mathrm{C}$ & 117.2 & 105 & 115 & 115 \\
\hline 46 & $2 / 98$ & 1.45 & 253 & 1.57 & 1.43 & 8.42 & 6.27 & $51^{\circ} \mathrm{C}$ & 113.2 & 105 & 115 & 115 \\
\hline 47 & $1 / 98$ & 1.32 & 41 & 2.37 & 0.62 & 3.76 & 1.85 & $39^{\circ} \mathrm{C}$ & 107.7 & 70 & 115 & 115 \\
\hline
\end{tabular}

* - Data for this table were obtained from the March Emergency Response Data [2]. Composition and liquid levels are updated monthly. The limits may change as a result of new sample results or level measurements.

**- Tw is the steel wall temperature. This temperature is measured on the sidewall of the tank.

BP- boiling point 
Table 2. Corrosion Chemistry Control Requirements

Applicability

1. $\left[\mathrm{NO}_{3}\right] \geq 1$ Molar

1a. $5.5<\left[\mathrm{NO}_{3}{ }^{-}\right] \leq 8.5$ Molar

1b. $2.75<\left[\mathrm{NO}_{3}\right] \leq 5.5$ Molar

1c. $1.0 \leq\left[\mathrm{NO}_{3}\right] \leq 2.75 \mathrm{Molar}$

2. $\left[\mathrm{NO}_{3}{ }^{-}\right]<1.0$ Molar

2a. Inhibit with $[\mathrm{OH}]$

OR

2b. - Inhibit with $\left[\mathrm{NO}_{2}{ }^{-}\right]^{*}$

$$
\text { For }\left[\mathrm{NO}_{3}^{-}\right] \leq 0.02 \mathrm{M}
$$$$
\left[\mathrm{NO}_{3}{ }^{-}\right]>0.02 \mathrm{M}
$$

$$
\text { For }\left[\mathrm{Cl}^{-}\right]
$$

For $\left[\mathrm{SO}_{4}=\right]$
Parameter

[OH]

$$
[\mathrm{OH}]+\left[\mathrm{NO}_{2}\right]
$$

$\left[\mathrm{OH}^{-}\right]$

$[\mathrm{OH}]+\left[\mathrm{NO}_{2}^{-}\right]$

$\left[\mathrm{OH}^{-}\right]$

$\left[\mathrm{OH}^{-}\right]+\left[\mathrm{NO}_{2}^{-}\right]$

[OH]

$\left[\mathrm{NO}_{2}{ }^{-}\right]$

$\left[\mathrm{NO}_{2}{ }^{-}\right]$

$\left[\mathrm{NO}_{2}{ }^{-}\right]$

$\left[\mathrm{NO}_{2}{ }^{-}\right]$

Minimum Needed (Molar)

0.6

1.1

0.3

1.1

$$
\begin{aligned}
& 0.1\left[\mathrm{NO}_{3}{ }^{-}\right] \\
& 0.4\left[\mathrm{NO}_{3}{ }^{-}\right]
\end{aligned}
$$

1.0

* - Calculate the minimum nitrite composition from each equation in $2 \mathrm{~b}$. The equation that gives the highest minimum value shall be used to calculate the minimum nitrite limit.

Table 3. Temperature limits in supernate $\left(\mathrm{T}_{\text {sup }}\right)$ with nitrate concentrations greater than 1 molar (M).

\begin{tabular}{|c|c|c|}
\hline Nitrate $(\mathrm{M})$ & $\mathrm{R}<2$ & $\mathrm{R} \geq 2$ \\
\hline $1-2.75$ & 70 & 105 \\
\hline $2.75-5.5$ & 105 & 112 \\
\hline $5.5-8.5$ & 70 & $*$ \\
\hline
\end{tabular}

* - Due to liquid solubility limitations it is not possible to have these supernate compositions.

$\mathrm{R}=\left\{\left[\mathrm{OH}^{-}\right]+\left[\mathrm{NO}_{2}\right]\right\} /\left[\mathrm{NO}_{3}\right]$

Table 4. Temperature limits for the salt/sludge phases and steel wall $\left(T_{s s}, T_{w}\right)$ with nitrate concentrations greater than 1 molar (M).

\begin{tabular}{|c|c|c|c|c|}
\hline & \multicolumn{2}{|c|}{$\mathrm{R}<2$} & \multicolumn{2}{c|}{$\mathrm{R} \geq 2$} \\
\hline Nitrate (M) & $\begin{array}{c}\text { Liquid Level }<120 \\
\text { inches }\end{array}$ & $\begin{array}{c}\text { Liquid Level } \geq 120 \\
\text { inches }\end{array}$ & $\begin{array}{c}\text { Liquid Level }<120 \\
\text { inches }\end{array}$ & $\begin{array}{c}\text { Liquid Level } \geq 120 \\
\text { inches }\end{array}$ \\
\hline $1-2.75$ & 105 & 115 & 105 & 115 \\
\hline $2.75-5.5$ & 105 & 115 & 112 & 122 \\
\hline $5.5-8.5$ & 105 & 115 & $*$ & $*$ \\
\hline
\end{tabular}

* - Due to liquid solubility limitations it is not possible to have these supernate compositions. 
Table 5. Temperature limits with nitrate concentrations less than 1 molar (M).

\begin{tabular}{|c|c|c|c|c|}
\hline & \multicolumn{2}{|c|}{$\mathrm{T}_{\text {sup. }}{ }^{\circ} \mathrm{C}$} & \multicolumn{2}{c|}{$\mathrm{T}_{\mathrm{w}}, \mathrm{T}_{\mathrm{ss}}}$, \\
\hline Hydroxide (M) & {$\left[\mathrm{NO}_{3}{ }^{-}\right] \leq 0.02 \mathrm{M}$} & $1 \mathrm{M}>\left[\mathrm{NO}_{3}{ }^{-}\right] \geq 0.02 \mathrm{M}$ & $\begin{array}{c}{\left[\mathrm{NO}_{3}^{-}\right] \leq 0.02} \\
\mathrm{M}\end{array}$ & $1 \mathrm{M}>\left[\mathrm{NO}_{3}{ }^{-}\right] \geq 0.02 \mathrm{M}$ \\
\hline$>8$ & 60 & 60 & 60 & 60 \\
\hline $1-8$ & 60 & 100 & 60 & 100 \\
\hline $0.01-1$ & 40 & 40 & 75 & 75 \\
\hline
\end{tabular}

Table 6. Analysis of "Dry" Tanks

\begin{tabular}{|c|c|c|c|c|c|c|c|c|c|c|}
\hline Tank & $\begin{array}{c}\text { Date of } \\
\text { Last } \\
\text { Sample }\end{array}$ & $\begin{array}{c}\text { Waste } \\
\text { Form }\end{array}$ & $\begin{array}{c}\text { Interstitial } \\
\text { Liquid } \\
\text { Volume } \\
\text { when tank } \\
\text { went dry } \\
\text { (gallons) }\end{array}$ & $\begin{array}{c}\text { \% of Tank } \\
\text { Volume } \\
\text { Occupied } \\
\text { by liquid }\end{array}$ & $\begin{array}{c}\text { Nitrite } \\
(\mathrm{M})\end{array}$ & $\begin{array}{c}\text { Nitrate } \\
(\mathbf{M})\end{array}$ & $\begin{array}{c}\text { Hydroxide } \\
(\mathrm{M})\end{array}$ & $\begin{array}{c}\text { Length } \\
\text { of time } \\
\text { tank has } \\
\text { been } \\
\text { dry } \\
\text { (yrs) }\end{array}$ & $\begin{array}{c}\text { Estimated } \\
\text { Hydroxide } \\
\text { Depletion } \\
\text { Time } \\
\text { (yrs) }\end{array}$ & $\mathrm{R}$ \\
\hline 2 & $12 / 10 / 96$ & Salt & 126,500 & 17 & 3.0400 & 2.2500 & 7.1800 & $<1$ & 25 & 4.54 \\
\hline 3 & $07 / 13 / 76$ & Salt & 121,000 & 16 & 2.7000 & 1.6000 & 9.4000 & 21.7 & 25 & 7.56 \\
\hline 5 & $03 / 01 / 73$ & Sludge & 41,000 & 4 & 3.1000 & 2.4000 & 4.4000 & 25 & 8 & 3.13 \\
\hline 8 & $11 / 26 / 85$ & Sludge & 163,100 & 22 & 0.9330 & 1.5350 & 0.5310 & 12.4 & 35 & 0.95 \\
\hline 9 & $01 / 11 / 73$ & Salt & 122,000 & 16 & 3.2000 & 1.9000 & 3.8000 & 25.2 & 25 & 3.68 \\
\hline 10 & $06 / 04 / 87$ & Salt & 50,000 & 7 & 0.3620 & 3.8170 & 0.8300 & 10.8 & 8 & 0.31 \\
\hline 12 & $11 / 29 / 84$ & Sludge & 151,760 & 20 & 2.8600 & 3.0800 & 1.3000 & 13.4 & 35 & 1.13 \\
\hline 14 & $10 / 06 / 81$ & Salt & 53,200 & 18 & 2.9000 & 3.7000 & 4.1000 & 16.5 & 8 & 1.89 \\
\hline 15 & $03 / 07 / 88$ & Sludge & 218,400 & 22 & 0.0960 & 1.1000 & 1.1160 & 10 & 35 & 1.10 \\
\hline
\end{tabular}

Footnotes:

(1) Total supernate includes the sludge interstitial liquid and the saltcake interstitial liquid. The interstitial liquid in the sludge is approximately $70 \%$ of the sludge volume, while for the saltcake interstitial liquid it is approximately $22 \%$ of the saltcake volume.

(2) The calculation for interstitial liquid volume assumes that the sludge or saltcake layer were saturated just prior to becoming dry. 
B. J. Wiersma

July, 1999
WSRC-TR-98-00131, Rev. 1

Page 15 of 15

Figure 1. Tank Temperature Decision Tree

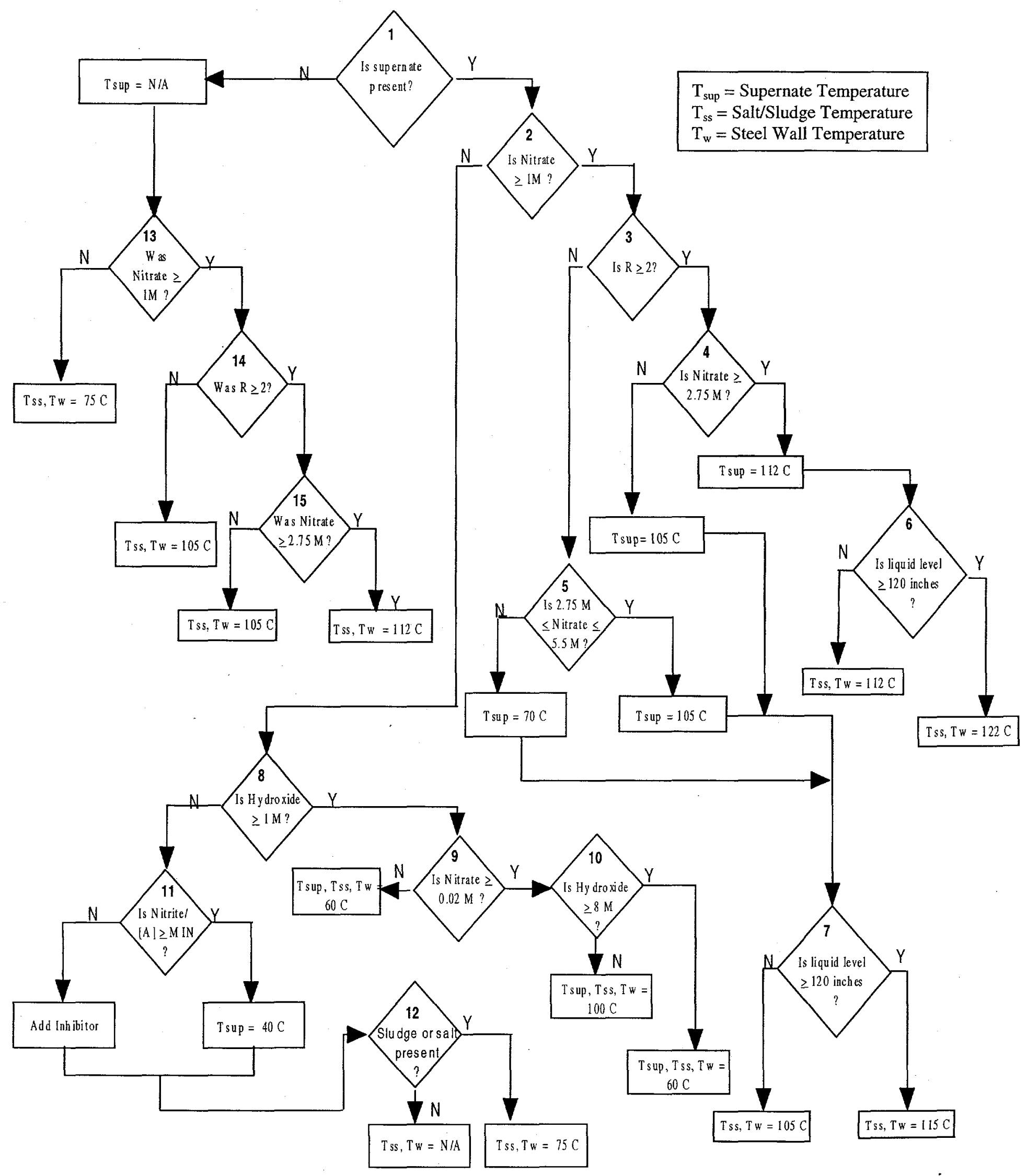




\section{Distribution}

W. T. Davis, 707-H

D. M. Grimm, 707-H

K. A. Hauer, 241-100F

C. G. Lampley, 241-100F

T. M. Monahon, 703-H

B. L. Lewis, 703-H

W. F. Bates, 707-H

R. L. Salizzoni, 707-H

R. H. Spires, 703-H

L. S. Livingston, 703-H

J. R. Hester, 703-H

M. J. Turek, 703-H

J. A. Pike, $704-196 \mathrm{~N}$

C. R. Wolfe, 773-A

N. C. Iyer, 773-41A

P. E. Zapp, 773-A

J. I. Mickalonis, 773-A

W. L. Tamosaitis, 773-A

S. D. Fink, 773-A

D. T. Hobbs, 773-A

E. D. Lee, 241-152H

CSTE Fileroom, 703-H

MTS Files, 773-A

Technical Information Management (4), 773-52A 